\title{
O enfrentamento do diagnóstico da doença falciforme: Desafios e perspectivas vivenciadas pela família
}

Coping sickle-cell disease diagnosis: Challenges and perspectives experienced by family

\author{
C. A. Ataide ${ }^{1 *} ;$ J. Ricas ${ }^{2}$ \\ ${ }^{1}$ Centro de Educação Superior a Distância/CESAD Universidade Federal de Sergipe/UFS, CEP:49100-000,Aracaju, \\ Sergipe, Brasil; \\ ${ }^{1}$ Faculdade de Medicina,Universidade Federal de São João Del Rei/UFSJ, CE:36307-352, São João Del Rei,Minas \\ Gerais, Brasil \\ cintiaataide@yahoo.com.br
}

(Recebido em 09 de novembro de 2016; aceito em 19 de abril de 2017)

\begin{abstract}
A doença falciforme (DF) é a doença genética mais comum no Brasil, com alta prevalência e morbimortalidade, consequente às diversas complicações, sendo considerada como um problema de saúde pública. O presente estudo teve por objetivo compreender o impacto do diagnóstico da doença falciforme no contexto familiar. Foram realizadas entrevistas semiestruturadas com 12 mães/cuidadoras de crianças portadoras da DF, diagnosticadas através da triagem neonatal - teste do pezinho e que estavam recebendo tratamento no Setor de Hematologia Pediátrica do Hospital Universitário Cassiano Antônio de Moraes HUCAM/UFES, em Vitória/ES. O resultado desse estudo retrata grande influência dos fatores socioeconômicos sobre a reação da família; restrita participação paterna no tratamento da criança; a dificuldade inicial na compreensão da comunicação diagnóstica pela influência da não visibilidade da doença, a associação direta da doença falciforme com síndromes e doenças mentais, favorecida pela falta de conhecimento popular sobre elas. Observamos que o apoio dos profissionais de saúde e da educação em saúde foi um facilitador no enfrentamento da doença.
\end{abstract}

Palavras-chave: doença falciforme, família, triagem neonatal.

The Sickle-cell disease is the most common genetic disease in Brazil, with a high prevalence and morbimortality rate due to several complications, being considered as a public health problem. This qualitative study attempts to understand the impact of sickle-cell disease diagnosis in the context of family. In this study were realized semi-structures interviews with 12 mothers/caretakers, whose children had received the diagnosis through the neonatal screening and were being aided in the Pediatric Hematology Sector of University Hospital Cassiano Antônio de Moraes - Hucam/UFES, in Vitória, Espírito Santo State. As a result, we noticed: a strong influence by social and economics factors on the family's reaction, especially the financial overload; the absence of the father participation on the child's treatment; the initial difficulty in understanding the diagnosis. It was also ascertained that the mother/caretaker's suffering is intensified by the child's pain. It is important to highlight that written informative material and Health Education meetings in the hematology sector strongly contributed to the understanding of the disease by the family.

Keywords: sickle-cell disease, diagnosis, family, neonatal screening.

\section{INTRODUÇÃO}

As hemoglobinopatias são as principais e mais frequentes doenças genéticas que acometem seres humanos, e dentre elas a Anemia Falciforme (AF) é a mais frequente no Brasil, chegando a acometer $0,1 \%$ a $0,3 \%$ da população negróide, com tendência a atingir uma parcela cada vez maior da população devido ao alto grau de miscigenação da população brasileira [1,2]. A denominação AF é reservada para a forma da doença que ocorre em homozigotos SS. Além disso, o gene da $\mathrm{Hb} \mathrm{S}$ pode combinar-se com outras anormalidades hereditárias das hemoglobinas, como hemoglobina $\mathrm{C}(\mathrm{Hb} \mathrm{C})$, hemoglobina $\mathrm{D}(\mathrm{Hb} \mathrm{D}), \beta$-talassemia, entre outros, gerando combinações que também são sintomáticas denominadas respectivamente, doença $\mathrm{SC}$, doença $\mathrm{SD}$, doença $\mathrm{S} / \beta$-talassemia. No conjunto, todas essas doenças são reconhecidas como Doença Falciforme (DF) e tem manifestações clínicas e espectro epidemiológico semelhante [3]. 
A Doença Falciforme é uma doença genética, crônica degenerativa, que apresenta severas intercorrências, principalmente nos primeiros cinco anos de vida. É uma doença genética com alto índice de morbimortalidade, consequente a complicações vaso-oclusivas como crises recorrentes de dor, síndrome torácica aguda, sequestro esplênico, priaprismo, necrose asséptica de ossos e acidentes vasculares cerebrais $[1,2]$.

Os portadores de DF são acometidos desde o início de suas vidas pelos fenômenos de vasooclusão, que tem como consequência a lesão tecidual irreversível dos diferentes órgãos. Tais lesões são responsáveis pela manifestação clínica mais característica da $\mathrm{DF}$, que é a dor em extremidades, região lombar, abdome ou tórax. A chamada crise álgica, manifesta comumente a partir dos 24 meses de vida. A dor é a causa mais comum de procura do serviço de emergência pelo paciente, e muitas vezes resultam em internação hospitalar [4].

Em virtude das graves manifestações clínicas da doença, da alta incidência e morbimortalidade, foi implantado, a partir de 2001, no Brasil, o diagnóstico precoce das hemoglobinopatias pela triagem neonatal / Teste do Pezinho [3,5].

A triagem neonatal visa detectar a doença falciforme de maneira mais rápida, possibilitando a condução de tratamento mais qualificado, tornando possível a prevenção das manifestações clínicas, minimizando as intercorrências e, consequentemente, aumentando a sobrevida e melhorando a qualidade de vida dos portadores.

No entanto, percebe-se que a constatação do diagnóstico da Doença Falciforme pode trazer implicações extremamente significativas para a vida dos familiares e do paciente. Mediante a uma situação diagnóstica grave, a família muitas vezes é atingida por uma intensa angústia e desorganização psicológica, o que pode resultar em profunda desestruturação da dinâmica familiar, gerando conflitos internos e desequilíbrio sistemático [6].

Menandro (1995) [7] aponta que quando uma família se defronta com o fato de um de seus membros nascer com alguma doença grave, há uma grande repercussão na estrutura psicodinâmica familiar. A família diante de uma doença grave é forçada a uma adaptação ou reajustamento para poder lidar com o problema.

$\mathrm{O}$ adoecimento, proporciona uma significativa exclusão do indivíduo doente. Aquele que não é saudável fica à margem, pois o senso comum preconiza que o sujeito doente não está ativo, nem para a vida, nem para o mundo [8]. A doença, além de ser um agente socialmente estigmatizante, provoca intensas rupturas internas no sistema familiar.

$\mathrm{O}$ adoecer muitas vezes é percebido como um evento ameaçador, perigoso, que impossibilita ao paciente e seu familiar atender às demandas da vida. Assim como o processo de adoecimento, o momento do diagnóstico pode também mobilizá-los de maneira semelhante. Inicialmente, a comunicação diagnóstica é um momento singular no qual paciente/familiares podem ser tomados por um "estado de choque" [9].

Com o processo de adoecimento o paciente e seus familiares necessitam de uma adaptação às mudanças que lhes são impostas: tanto as atividades rotineiras, quanto os planos e projetos para o futuro são interrompidos, ocorre perda da condição de sujeito sadio, e por fim o paciente e seus familiares enfrentam grande ansiedade frente à iminência da morte e as limitações advindas pelo adoecimento.

O diagnóstico precoce tornou-se um diferencial no tratamento da Doença Falciforme, no entanto, compreender as reais implicações dessa doença para o contexto familiar, pode minimizar os sofrimentos advindos desse processo, além de contribuir para uma postura mais ativa na aceitação da doença, garantindo um tratamento de qualidade e eficiente aos pacientes.

\section{MATERIAL E MÉTODOS}

O estudo de característica qualitativa buscou compreender os desafios e perspectivas de enfrentamento do diagnóstico da doença falciforme no contexto familiar. Do ponto de vista metodológico, a pesquisa qualitativa é uma ferramenta indicada para estudar os aspectos subjetivos dos fenômenos psicossociais do ser humano, entre os quais, a vivência de doenças [10]. 
Nessa perspectiva, o método qualitativo visa apreender com o devido grau de complexidade os aspectos subjetivos advindos do processo de diagnóstico da doença falciforme, pois busca um maior entendimento dos fatos, crenças e fenômenos que se estruturam por meio das interações entre a dinâmica da vida individual e/ou coletiva do ser humano.

Chizzoti (1995) [11] retrata que na abordagem qualitativa há uma relação dinâmica entre o mundo real e o sujeito, uma interdependência viva entre o sujeito e o objeto, um vínculo indissociável entre o mundo objetivo e a subjetividade do sujeito (pg.79). Através de uma ótica dinâmica, o fenômeno estudado não pode ser compreendido como neutro e estático, mas enquanto objeto repleto de significações e relações com os sujeitos concretos.

A pesquisa qualitativa visa ampliar o entendimento acerca dos processos interpessoais que o indivíduo mantém com os outros e com o mundo, além de apreender de maneira bastante significativa o conjunto de expressões humanas integradas a estruturas, processos, significados e representações [12]. Em virtude desta inter-relação que o indivíduo mantém com o mundo, a análise qualitativa torna-se uma ferramenta para a melhor compreensão das realidades vivenciadas pelos pais e/ou cuidadores que receberam a constatação diagnóstica da Doença Falciforme.

Para compreensão dos desafios e perspectivas de enfrentamento da doença falciforme, todas as etapas desse estudo foram pautadas pelos princípios da Bioética, que se baseia no respeito e na necessidade de resgatar o sujeito moral, participativo e autônomo que está envolvido na pesquisa [13]. Desta maneira, o presente estudo buscou disponibilizar a consciência crítica em todos os processos da pesquisa, bem como considerar tanto no nível individual quanto no coletivo a dignidade humana ali inserida. Importante destacar que não houve quaisquer tipos de risco ou dano aos participantes da pesquisa, seja nas esferas física, moral ou material. Todos os dados obtidos foram publicados com nomes fictícios/ e ou siglas, com a finalidade de resguardar as identidades dos participantes da pesquisa e dos profissionais envolvidos no tratamento do paciente e da família.

A partir das considerações feitas pela resolução 196/96 do Conselho Nacional de Saúde/CNS em Pesquisa que envolve seres humanos, o estudo iniciou após aprovação do Comitê de Ética em Pesquisa da Universidade Federal de Minas Gerais/UFMG e do Comitê de Ética de pesquisa do Hospital Cassiano Antônio de Moraes /HUCAM da Universidade Federal do Espírito SantoUFES. De acordo com as diretrizes da resolução196/96, a pesquisa foi delineada por 04 referenciais básicos da Bioética, que são os princípios de Autonomia, Não Maleficência, Beneficência e Justiça/Equidade.

De acordo com o critério de inclusão na pesquisa, os participantes da pesquisa foram pais e/ou cuidadores que receberam a constatação diagnóstica da Doença Falciforme através da Triagem Neonatal, cujas crianças estivessem na idade entre 06 e 14 meses. Através de prontuários foram escolhidos os participantes que se enquadravam nos critérios da pesquisa, e no dia da consulta médica os pais e/ou cuidadores foram convidados para participação da pesquisa.

Os sujeitos convidados eram esclarecidos acerca dos objetivos da pesquisa e a entrevista era conduzida após livre consentimento e assinatura do termo de consentimento livre e esclarecido do participante.

Para a coleta de dados utilizou-se a entrevista semi-estruturada, e para registrar integralmente as informações durante a coleta de dados foi solicitado a autorização do uso do gravador. $\mathrm{O}$ número da amostra não foi previamente determinado. Para estabelecê-lo utilizou-se o "Critério de Saturação" [14,15]. De acordo com esse tipo de critério, o número ideal de entrevistas é atingido quando respostas começam a ser repetidas pelos novos sujeitos que se vão acrescentando à amostra. Durante a entrevista, foi realizada uma análise inicial (pré-análise), com o objetivo de verificar a saturação da amostra e o surgimento de algum dado que pudesse redirecionar a coleta ou os objetivos do estudo.

Neste estudo contamos com 12 sujeitos (mãe/ e ou cuidadora), tendo a saturação ocorrida na nona entrevista, no entanto, optou-se por realizar mais três entrevistas, a fim de reforçar a saturação, garantindo melhor apreciação dos dados.

A técnica de análise do conteúdo foi escolhida para a lapidação dos dados obtidos. O Discurso do Sujeito Coletivo (DSC) foi o instrumento utilizado para a categorização e organização dos resultados da pesquisa. O DSC consiste na técnica de agregar discursos individuais sobre um 
determinado tema, de forma que eles expressem o pensamento de uma coletividade. Essa proposta visa a alcançar o imaginário coletivo sobre um determinado tema, uma determinada ordem social, num dado momento histórico [16].

\section{RESULTADOS E DISCUSSÃO}

Participaram desse estudo dez mães biológicas, uma tia e uma mãe adotiva. De acordo com os relatos, os pais raramente acompanham seus filhos às consultas e tratamento. A sobrecarga financeira provocada pelos gastos com a criança foi uma presença relevante nas falas das mães. Nesse quadro social, um dado que merece atenção foi o fato de a mãe ser frequentemente a principal ou a exclusiva cuidadora da criança.

Outro dado que reforça a identidade da amostra é a existência significativa de famílias, em que o pai e mãe da criança doente não vivem juntos. Verificamos nesses casos, que parcela significativa desses pais não acompanha, nem ajuda financeiramente, o tratamento da criança. Neste estudo apenas um pai demonstra, segundo relato da mãe, certa preocupação acerca da doença da criança. Quanto ao perfil das famílias estudadas, a maioria é monoparental, apresenta um número médio de 04 pessoas na residência e uma renda menor ou igual a um salário mínimo, caracterizando um nível sócio econômico baixo.

Em relação ao impacto do diagnóstico da doença falciforme os dados foram categorizados em 04 temas centrais:

Tabela 1: Temas Centrais

\begin{tabular}{|l|l|}
\hline Tema 01 & Sentimentos e reações no recebimento do diagnóstico \\
\hline Tema 02 & $\begin{array}{l}\text { Percepções sobre a comunicação do diagnóstico e compreensão } \\
\text { acerca da doença }\end{array}$ \\
\hline Tema 03 & $\begin{array}{l}\text { Principais mudanças, dificuldades e preocupações da família após } \\
\text { o diagnóstico da doença falciforme. }\end{array}$ \\
\hline Tema 04 & Estratégias de enfrentamento da família para melhor aceitação da \\
\hline
\end{tabular}

Através da vivência relatada pelas cuidadoras, verifica-se que o diagnóstico da Doença Falciforme tem implicações significativas para a vida da família. Além do sofrimento psíquico e das diversas adaptações, mudanças, inseguranças e limitações que são provocadas pelo diagnóstico da doença falciforme, há também os componentes de ordem social, tais como desestruturação familiar, baixo poder aquisitivo e desemprego, que intensificam ainda mais o impacto do diagnóstico.

Em relação ao tema 01: Sentimentos e reações no recebimento do diagnóstico, o impacto inicial está demarcado por reações de choque pelo inesperado, de revolta pelo adoecimento da criança, pelo susto, pela tristeza, pelo desespero, e muitas vezes pelo medo do desconhecido. $\mathrm{O}$ relato a seguir retrata essa situação inicial:

"[...] quando a gente descobre assim, eh... dá um choque, né? E aí a gente fica... poxa! Muitas vezes a gente até se pergunta, né? Por que isso aconteceu comigo?... no inicio foi difícil[...]" (D04).

As famílias estudadas apontam nesse momento inicial o medo de que a alteração encontrada, no teste do pezinho, fosse alguma doença mental. Esse aspecto pode ser um reflexo cultural, que associa diretamente o Teste do Pezinho ao diagnóstico de deficiências mentais [17,18,19], apesar do fato de que ele já vem fazendo a detecção precoce de diversas patologias.

"Fiquei preocupada, né? Achei que ela tava com problema, deeee [...] aquela doença [...] Eh, esses problemas que dá nas crianças que ficam abobadas, achei que fosse isso [...]" (L11).

O discurso coletivo relacionado ao tema 01: Sentimentos e reações no recebimento do diagnóstico: 
"Recebi a notícia, que era para eu comparecer na Apae, procurar no dia marcado a Dra. $N$ sobre o problema da $\boldsymbol{E}$ que saiu no teste do pezinho! Ai eu pensei, ih será que a menina é excepcional? Na hora eu fiquei desesperada, né? [...] eu comecei foi chorar, chorar também, né? por causa dela...porque eu não sabia como era esse negócio [...] na hora, eu pensei que tinha aqueles problemas assim, tipo Síndrome de Down, [...] me mandaram procurar a Apae, né ? Quando eles falaram que era da Apae, eu fiquei imaginando, né?. pra mim a Apae era lugar onde tinha doença assim [...] eu achei que tinha alguma coisa, tipo [...] síndrome de [...] ai a moça falou que a doença não ia afetar o cérebro não!

No início eu não entendia muito bem, não entendia bem o assunto, né? [...] eu fiquei preocupada [...] não sabia direito qual ia ser a reação assim nela [...] sei lá, foi um susto, né? Assim [...] foi uma coisa nova, né?! Eu nunca ouvi falar sobre essa anemia. Porque eu não sabia o que era! Ah, logo ela falou que não tem cura, só tem tratamento. Ai eu vim chorando [...] Na hora eu fiquei desesperada, né? [...] eu comecei foi chorar, chorar também, né? Por causa dela [...] porque eu não sabia como era esse negócio [...] será que vai morre?! Para mim era uma doença assim [...] primeiro era uma doença perigosa, né?! Podia levar a qualquer hora à morte não sei [...]

Eu, assim, planejei durante 02 anos praticamente, né?! pra ficar grávida, daí quando nasce, você vê uma criança perfeita, né?! Mas saber que ela tem um problema foi um choque! [...] você vê que ela, não tem nada! Mas eu que sou mãe, eu sei que no fundo, no fundo, ela tem uma coisinha, [...] então sei que isso prejudica à ela, né?! Que ela vai sentir as dores, né?!Que ela é uma criança mais frágil!

Foi difícil, [...] porque a gente sempre quer que os nossos filhos venha saudável, né?! Então quando a gente descobre assim, eh, dá um choque, né?Achei que eu tinha que manter ela presa, porque senão eu poderia perder a minha filha, isso é que eu pensei no início! E ai a gente fica [...] poxa! Muitas vezes a gente até se pergunta, né? Por que isso aconteceu comigo?”

No tema 02: Percepções sobre a comunicação do diagnóstico e compreensão acerca da doença, verifica-se que não houve relato sobre a postura do profissional de saúde no momento de transmitir o diagnóstico da criança. Apesar de ser um dado de grande interesse, os entrevistados avaliaram apenas a adequação do conteúdo do que foi transmitido. Os discursos de uma maneira geral apontam a comunicação do diagnóstico de forma adequada. No entanto, observa-se que há certa dificuldade no entendimento concreto sobre a doença, fato que pode ter sido acentuado pelo sofrimento psíquico, intenso, nesse momento inicial do diagnóstico.

As principais preocupações da família após o diagnóstico da doença falciforme foram com as intercorrências e sequelas da doença, que, no imaginário dos sujeitos, estão fortemente associadas à possibilidade de morte:

"Ai eu fico preocupada, assim [...] achando assim que ele..., que ele pode dar alguma [...] Ah porque a Dra. falou assim que ele pode até morrer, se ele, se ele não fosse cuidado direito" $(\mathrm{C} 03)$.

O cuidado integral da criança é uma das principais mudanças e dificuldades retratadas pelos sujeitos da pesquisa, geralmente a mãe abre mão do trabalho, da vida social e vive exclusivamente para a criança doente. Um dos diversos conflitos se instaura nesse momento, pois, para garantir o tratamento, as mães deparam com a necessidade de trabalhar e se veem impossibilitadas, devido à demanda muito grande em relação ao cuidado e ao tratamento:

"Sinto falta do emprego, pra poder cuidar da minha filha, de um lugar pra eu morar, porque eu moro com a minha mãe, dependo dela pra tudo! [...] era pra eu ter ido embora de casa, só não fui por causa da menina! É uma barra! Por isso eu falo, se ela [...] não tivesse esse probleminha, eu já tinha arrumado um jeito de sair daquela casa de minha mãe, mas eu [...] penso mais na minha filha [...]." (E05).

O discurso coletivo relacionado ao tema 02: Percepções sobre a comunicação do diagnóstico e compreensão acerca da doença: 
"A médica falou comigo que deu uma alteração no sangue dela, que o exame dela, deu uma anemia, chamada Anemia Falciforme. Há! Logo ela falou que não tem cura, só tem tratamento [...] Na hora eu fiquei desesperada, né? Porque eu não sabia como era esse negócio! Aí, despois pensei que foi ser uma anemia simples, né? Ah! Despois eu entendi que não era uma Anemia simples, e ai que eles me deu a apostila, que eu comecei a ler e entender, eu sei que agora não é simples. Eles fala que é simples mas, não é simples, não ! Eles só fala pra gente não ficar com medo. Aí, eu só fui entender depois de meses [...]

A Dra. O ela me falou direitinho, que é uma doença que tem que ter muito cuidado, tem que tá sempre atento! Aí, explicou pra gente sobre os sintomas, as vacinas e explicou como que, que é formada a doença, né? Que é genético, os traços do pai e da mãe [...] Na hora eu não entendi nada, né?... Eu fiquei muito confusa, o que veria a ser? O que ela ia sentir, Aí, eu vim chorando [...] Aí, ela me deu um panfletozinho, né? Aí, eu peguei e comecei a ler! Eu li e relia toda hora.

Eu participei da Reunião, vi o pessoal falando, ai eu entendi! ...que ia inchar a mãozinha e o pezinho, a febre dela pode ser uma coisa que pode se alterar, de repente o baço pode inchar [...] ah! Assim chegar no hospital informar logo que tem a doença e atender o mais rápido [...] só o baço dela que aumentou por causa da febre eu levei lá no HIABA. Observar a cor, a palidez! Tem vez que ela tá bem, tem vez que ela fica amarela, tem que sempre olhar o "bacinho", se inchar tem que levar pro hospital."

As Principais mudanças, dificuldades e preocupações da família após o diagnóstico da doença falciforme retratada no tema 03, sinalizam que as intercorrências e sequelas da doença são as principais preocupações das mães e cuidadoras. Importante destacar que tais preocupações estão fortemente associadas à possibilidade de morte:

"Ah! sobre ela eu me preocupo com tudo! Deus me livre se ela faltar, né? Eu tenho medo mesmo! Ah medo da doença piorar, ao caso né?! A doença piorar e eu perder minha neném, nossa!" (A01)

Sabe-se que, em relação à doença falciforme, a taxa de mortalidade é muito alta nos primeiros anos de vida, fato bastante trabalhado em reunião de Educação em Saúde, visto a importância da família na atenção, nos cuidados e na identificação dos sinais e sintomas da doença. A consciência desses fatos pode explicar que seja, na verdade, a morte a principal preocupação das mães com as crianças:

"Minha preocupação é ter um controle da anemia dela. Porque ela toma bezetacil de $21 \mathrm{em} 21$ dias, toma o acido fólico, quase sempre ela tá no hospital internada, essa é a minha preocupação! As vezes pode dar uma complicação [...] Então eu fico preocupada com o problema dela, e não dê tempo de correr pro hospital [...]" (I09)

Em virtude da gravidade da doença e sua alta taxa de mortalidade, a responsabilização da família é muito alta, no que se diz respeito ao tratamento e cuidado da criança. Isso gera grande stress e sofrimento para o cuidador, pois ele tem que saber identificar algum sinal ou sintoma e agir no tempo certo. Em nosso estudo, esse dado apresenta - se de forma expressiva:

"[...] Se ela morre nos vai sofrer muito! Então eu corro atrás, a vacina dela é tudo em dia, entendeu?" (H08)

Além da preocupação com a doença em si, os problemas psicossociais apareceram como um segundo eixo em torno do qual giram as inquietações da família. Os cuidados e o tratamento da doença falciforme acarretam aumentos nos gastos, o que representa uma das principais dificuldades enfrentadas pela família. Em virtude das dificuldades financeiras, as mães expressam receio de não conseguir manter os cuidados exigidos com a criança: 
"Eu se preocupo muito com o remédio, né? Igual esse remédio que ela toma. Eu vou no posto pegar, que é o ácido fólico, né? Lá a pediatra dela me dá! Passar remédio e eu não conseguir comprar, né?" (B02)

O discurso coletivo relacionado ao tema 03: Principais mudanças, dificuldades e preocupações da família após o diagnóstico da doença falciforme:

"Ah, sobre ela eu me preocupo com tudo! eu tenho medo mesmo da doença piorar, ao acaso né? Eu se preocupo muito porque a Dra. falou assim que pode até morrer, se não fosse cuidado direito [...] Que tem que ter vários cuidados! Eu, sei que ela é uma criança mais frágil que as outras, né? Que ela assim, se tiver uma febre eu tenho que ir ao hospital pra saber o que é! As vezes pode dar uma complicação [...] Então eu fico preocupada se não dê tempo de correr pro hospital [...] Se ela morre, nos vai sofrer muito!

Minha preocupação é ter um controle da anemia dela. Eu tenho que tá sempre fazendo o tratamento! tem que ta sempre tomando o remédio, as injeções, né? Porque ela toma Bezetacil de 21 em 21 dias, toma o Ácido Fólico, quase sempre ela tá no hospital internada, essa é a minha preocupação!

Minha Preocupação é não saber agir no momento [...] não saber agir na maneira certa, [...] as vezes eu nem durmo, fico vigiando ela, né? Tem que ta olhando toda hora, que ela faz muita febre, sabe? Qualquer hora o baço dela pode crescer [...] é muita coisa!

Eu se preocupo muito com o remédio, né? Igual esse, que é o Ácido Fólico, né? a pediatra dela me dá! o Bezetacil aonde eu moro, eu tenho que comprar, muitas vezes atrasa, por eu não ter o dinheiro! E os exames, que não são feitos de graça, eu tenho que pagar! Porque é igual ao salário que ela poderia se aposentar, e eu não consegui, né?! Então pra mim fica difícil!

Eu to parada, sem trabalhar! porque eu não consigo trabalhar por causa dela, é muito difícil, não ter ajuda de ninguém! não tenho nenhum tipo de ajuda, nem o dinheiro da passagem, igual vir pra cá é muita dificuldade! eu não posso me virar, mas infelizmente eu sô sozinha por parte dela! O pai dela, a gente se separou, né? ele é uma pessoa que não conto. E os problemas dela é só comigo. Só sei que eu seguro uma barra danada! Não posso trabalhar, porque tenho que levar essa menina pra médico! tem que levar na APAE, nas Clinicas, na pediatra dela, então eu acho assim[...] ]muito assim carregado, eu acho cansativo.

A minha outra menina é que fica me falando [...] que eu só fico com a neném, levando ela pro médico, mas os outros meninos não, já compreende mais... só a de 05 anos fica mais sentida [...] fica muito triste porque eu fico mais fora, do que em casa, né? Então ela fica assim meio sentida [...] triste, deprimida, ela demonstra"

O tema 04 retrata as principais estratégias de enfrentamento da família para melhor aceitação da situação de adoecimento. A negação é a principal reação ao receber o diagnóstico da Doença Falciforme. Como estratégia de ajustamento diante do stress provocado pela doença, a família, inicialmente, evita falar do assunto:

"[...] no começo foi difícil, eu nem gostava que tocasse no assunto [...] Ah, porque isso me incomodava, eu não aceitava... Não sei... eu ficava com pena dela, medo dela ficar sofrendo, de ficar doente, de ter complicações, e nem queria que ela ficasse internada no hospital, por isso eu nem gostava de ficar comentando Não aceitava, os meus filhos tudo bom e porque a L é assim?" (L11).

Esse mecanismo, no entanto, como em todas as doenças evolutivas, não tem como se manter diante da realidade do sofrimento físico e da necessidade do tratamento, sendo substituído gradativamente por outros mais adequados:

"[...] eu fiquei triste, mas hoje em dia... eu tenho como uma meta na minha vida! Cuidar o máximo possível da minha filha! Dar amor, carinho pra ela! [...] Esquecer que ela tem essa doença!” (D04). 
A fé religiosa foi outra estratégia utilizada para lidar melhor com a condição de adoecimento da criança. Verifica-se que os discursos apontam a importância das ações de educação em saúde na contribuição de um melhor entendimento sobre os aspectos da doença, deixando a família mais segura, contribuindo para um tratamento mais adequado da criança. $\mathrm{O}$ discurso coletivo aponta a educação em saúde como uma estratégia eficaz para diminuir o sofrimento, manter a esperança, pois é retratada como dispositivo sustentador, resgatando o papel ativo da família como responsável pelo cuidado da criança:

"Há pensei que ele ia morrer! porque qualquer crise que ele desce [...] Encaminhou para cá! Ai eu vim [...] a Dra. P conversou também! Ai eu participei da reunião, vi o pessoal falando, ai eu entendi!'”(C03)

No momento inicial do diagnóstico da doença falciforme, foi evidenciado um dado peculiar a essa doença, que é a não-visibilidade, devido à ausência de sinais e sintomas no primeiro ano de vida da criança. Quando a família depara com a notícia da doença, porém não percebe a criança doente, os conflitos e sofrimentos psíquicos provocados são prolongados, sobretudo pela negação do adoecimento [20,21]. Em alguns casos, a adesão ao tratamento da criança foi prejudicada em função desse processo.

$\mathrm{O}$ fato de a doença ser ainda desconhecida popularmente pode ter contribuído para a intensidade e prolongamento do sofrimento e permitiu que inicialmente o diagnóstico da doença falciforme fosse associado com doenças mentais, pelo fato de o diagnóstico ser feito pelo teste do pezinho. A fantasia de presença de doenças mentais e síndromes é um agravante do sofrimento familiar .A referência das mães às questões genéticas da doença, foi um dado ausente no discurso coletivo.

A postura do profissional de saúde quando transmitem o diagnóstico da criança, não foi retratada, apesar de ser um dado de grande interesse. Os entrevistados avaliaram apenas a adequação do conteúdo do que foi transmitido. Supõem-se que o fato de o pesquisador ser um profissional de saúde e de certa forma, ter participado da rede de atendimento da criança pode ter influenciado a não-avaliação da conduta dos profissionais que transmitiram o diagnóstico.

Como estratégia de enfrentamento, a negação é a principal reação ao receber o diagnóstico da Doença Falciforme. Como necessidade de ajustamento diante do stress provocado pela doença, a família, inicialmente, evita falar do assunto.

O discurso coletivo relacionado ao tema 04: Estratégias de enfrentamento da família para melhor aceitação da situação

“[...] no começo foi difícil, né! Porque eu não entendia direito [...] eu nem gostava que tocasse no assunto, ah porque isso me incomodava, eu não aceitava [...] Não sei, eu ficava com pena, medo, [...] medo de ficar sofrendo, de ficar doente, de ter complicações, e nem queria que ela ficasse internada no hospital, por isso eu nem gostava de ficar comentando.

Não aceitava, os meus filhos tudo bom e porque a L é assim? Eu quero que ela seja uma criança normal! Que ela é uma criança normal! E num, fique pensando, que ela tem esse problema! Pensar sim, é claro! Cuidar sim! Mas em certos momentos esquecer, né? Porque a gente fica lembrando muito, a gente acaba ficando triste!

Uma pessoa falava uma coisa, outra falava outra, aí ensinava dar um remédio, assim não adianta, porque não tem cura...mas é uma barra, quem tem uma criança com Anemia Falciforme. Nossa! Eu tive foi um pesadelo no começo! Uma barra assim, é ter um neném assim com esse problema, né?! Nessa idade, assim, eu vejo as outras crianças andando, brincando! Só fico assim, olhando [...] nossa é terrível! Eu tenho pena da minha filha, pois todas as crianças são quase normal, só ela tem esse problema! Isso é uma barra!...eu fiquei triste, mas hoje em dia [...] eu tenho como uma meta na minha vida cuidar o máximo possível da minha filha!

Há, porque isso me incomodava, eu não aceitava [...] lógico que a gente não gostaria, mas já que tem, é levantar a cabeça, encarar da melhor maneira, né! mas é lógico que tem coisa pior,né 
? Ai hoje em dia eu tô mais eh,não conformada, mais assim, eh, eu acostumei porque a gente sempre quer que os nossos filhos venha saudável, né?!

Então quando a gente descobre assim, [...] dá um choque, né? E ai a gente fica [...] poxa! Muitas vezes a gente até se pergunta, né? Porque isso aconteceu comigo? Mais no inicio foi difícil! Mas eu, eu, não me desesperei! Tem que ter fé em Deus pra tudo! Qualquer tipo de doença tem que ter fé em Deus [...] calma, tranquilidade [...] Porque eu acho que a pessoa com a cabeça no lugar é o essencial! Levar na médica que sabe da doença certinho! Ir pelo tratamento da médica e ter segurança em Deus né?

Perguntar a Deus: porque a minha filha teve essa doença? Só que às vezes Deus permite coisas na vida da gente, né? E a gente vai chorar, vai ficar perguntando o porquê, vai perder noite de sono! colocar Deus na frente, e depois procurar ajuda também, né? ajuda dos médicos e qualquer dúvida que tiver perguntar, se tiver dúvida pergunta, de tudo, tudo mesmo [...] se tiver que fazer eu vou fazer, agora se tiver alguma coisa que tiver pro lado dos médicos com certeza vai pras mãos dos médicos [...] manter-se calma e cuidar da criança".

\section{CONCLUSÃO}

O fato do desconhecimento da Doença Falciforme pode ter sido um fator que acentuou o sofrimento da família diante do diagnóstico da doença. Estudos apontam que medidas preventivas no tratamento da doença falciforme, como orientações à família para o reconhecimento precoce das complicações mais frequentes, reduzem a taxa de mortalidade do paciente para menos $5 \%$ nos primeiros anos de vida [22].

A educação em saúde foi um fator de grande relevância para um melhor conhecimento dos sintomas e sinais da doença. As famílias apresentam maior responsabilização no cuidado e tornam-se mais seguras no tratamento da sua criança.

Os profissionais de saúde em todos os espaços de formação devem priorizar a importância no apoio à família. Urge a necessidade em oportunizar um espaço de escuta para essas famílias, permitindo a expressão de suas vivências, seus sofrimentos, suas angústias e, sobretudo o entendimento de suas dificuldades de compreensão e suas demandas. Nesse sentindo ampliará as tentativas de apoio e a participação cooperativa no tratamento da família e paciente.

Como sugestão de melhoria contínua na assistência ao portador da doença falciforme, torna-se necessário a implantação de grupos de apoio ao diagnóstico, para a família. Torna-se relevante a construção de um espaço de apoio, escuta, reflexão e trocas de experiências, onde a família tivesse a possibilidade de discutir as suas dúvidas com equipe de saúde e outras famílias, contextualizando a nova situação no seu cotidiano, se organizando e mobilizando ações de melhorias no cuidado da criança.

Campanhas de divulgação das características da doença, sua natureza genética e as possibilidades de assistência e tratamento podem também ser úteis na compreensão da doença e na mobilização popular para apoio emocional às famílias afetadas. Além disso, será de utilidade na prevenção dos agravamentos da doença, garantindo mais qualidade de vida para a família e a criança portadora da doença falciforme.

\section{REFERÊNCIAS BIBLIOGRÁFICAS}

1. Bandeira, FMGC et. al. características de recém-nascidos portadores de hemoglobina $\mathrm{S}$ detectados através de triagem em sangue de cordão umbilical. J Pediatr. 1999;(75):167-171.

2. Silla, LMR. Doença Falciforme: um grave e desconhecido problema de saúde pública no Brasil. J Pediatr. 1999;75(3):145-146.

3. Brasil. Ministério da Saúde. Portaria GM/MS n. ${ }^{\circ} 822$, de 6 de junho de 2001. Disponível em: <http://dtr2001.saude.gov.br/sas/PORTARIAS/Port2001/GM/GM-822.htm>.

4. Dover GJ, Platt OS. Sickle Cell Disease. In: Nathan DG, Orkin SH editors. Hematology of Infancy and Childhood. $5^{\text {th }}$ edition, Philadelphia:W.B. Saunders Company. 1998;(1):762-809.

5. Brasil. Ministério da Saúde. Portaria n. ${ }^{\circ 2.695 / G M, ~ d e ~} 23$ de dezembro de2004. Disponível em: <http://dtr2001.saude.gov.br/sas/PORTARIAS/Port2004Port2004/Gm/GM-2695.htm>. 
6. Campos, EMP, Alvares, M, Abreu, P. Infância e família. In: Filho, MJ; Burd, M. (Org.). Doença e família. São Paulo: Casa do Psicólogo, 2004;(10):205-215.

7. Menandro, MCS. Convivência Familiar com Afetado por Distrofia Muscular de Duchenne: da Comunicação às Estratégias de Enfrentamento. Dissertação de Mestrado apresentado a Universidade Federal do Espírito Santo; 1995. 174p.

8. Goffman, E. Estigma: notas sobre a manipulação da identidade deteriorada. 4. ed. Rio de Janeiro: LTC; 1988.

9. Silva CMF, Ataide CA. Avaliação da Percepção da Qualidade de Atendimento Prestado as Crianças e Adolescentes Portadores de Doença Falciforme: Uma Análise a Partir da Opinião de Pais e Cuidadores, 2002. Anais do XVII Congresso Espiritossantense de Pediatria,Vitória.

10. Tomazi, NGS, Yamamoto, RM. Metodologia de pesquisa em saúde: fundamentos essenciais. Curitiba: As autoras; 1999.

11. Chizzoti, A. A pesquisa em ciências humanas e sociais. 2. ed. São Paulo: Cortez; 1995. 77-87.

12. Minayo, MCS (org.) Pesquisa Social: Teoria, método e criatividade. 22 ed. Petrópolis: Editora Vozes; 2003.

13. Pessini, L.; Barchifontaine, C P. Bioética: alguns desafios. São Paulo: Loyola; 2001.

14. Turato, ER. Tratado da metodologia da pesquisa clínico - qualitativa: construção teóricoepistemológica, discussão comparada e aplicação nas áreas da saúde e humanas. 2. ed. Petrópolis: Vozes; 2003. 685p.

15. Deslandes, SF. A construção do projeto de pesquisa. In: MINAYO, M.C.S. (Org.). Pesquisa social: teoria, método e criatividade. 2. ed. Petrópolis: Vozes; 1994. 31-50.

16. Lefèvre, F, Lefèvre, AMC. O Discurso do sujeito coletivo: um novo enfoque em pesquisa qualitativa. Desdobramentos. Caxias do Sul (RS): EDUCS, 2003,256.

17. Souza, RC, Scatena, MCM. Produção de sentidos acerca da família que convive com o doente mental. Rev Latino-Am Enfermagem. 2005 mar/abr;13(2):173-179.

18. Cavalcante, F. Família, subjetividade e linguagem: gramáticas da criança "anormal". Rev Ciênc Saúde Coletiva. 2001;6(1):125-137, doi: 10.1590/S1413-81232001000100011.

19. Silva, NLP, Dessen, MA. Deficiência mental e família: implicações para o desenvolvimento da criança. Psic Teor e Pesq. 2001;17(2):133-141.

20. Castro, EK, Piccinini, CA. Implicações da doença orgânica crônica na infância para as relações familiares: algumas questões teóricas Psicol Reflex Crit. 2002;15(3):625-635.

21. Tetelbom, M. Falceto, OG, Gazal, CH, Shansis, F, Wolf, AL. A criança com doença crônica e sua família: importância da avaliação psicossocial. J Pediatr. 1993;69(1):5-11.

22. Lobo, CLC. et al. Triagem neonatal para hemoglobinopatias no Rio de Janeiro, Brasil. Rev Panam Salud Publica Washington. 2003;13(2):154-159. 